\title{
ON MULTIPLE DIMENSIONS OF CRITERIA REPRESENTING FINANCIAL GLOBALISATION
}

\author{
Askoldas Podviezko \\ Department of Social Economics and Management, Faculty of Business Management, \\ Vilnius Gediminas Technical University, Sauletekio 11, Vilnius, Lithuania \\ E-mail: askoldas@gmail.com
}

\begin{abstract}
A prevailing contemporary concept of major researchers in the field of economics suggests that financial globalisation creates positive effect on economic growth. Besides this crucial hypothesis many other related with financial liberalisation hypotheses are being tested. Financial liberalisation is an integral part of globalisation. Quantitative gauging of the level of globalisation creates opportunities for more precise identification of causes of prominence or lagging of the home country or any other country in question in comparison with its peers, and creates possibilities to analyse if the country is fully realising its economic potential. Analysis of criteria and their categories, which reflect the level of financial globalisation, is a compulsory step for any quantitative evaluation. The purpose of the study is to reveal importance of accurate evaluation of the level of financial globalisation for allowing further important research to be carried out on such prime economic processes as economic growth, corruption; income inequality; politics; financial stability; prudential policy, to provide a brief overview of the variety of existing approaches available in the literature, which attempt to quantitatively evaluate the level of financial globalisation.
\end{abstract}

Keywords: financial globalisation, economic growth, financial liberalisation, category, quantitative criteria, bank-based financial system, market-based financial system.

JEL Classification: G01; G28; H12; F15; F38; F43; F62; D31.

\section{Introduction}

Two historical preconditions made the topic of evaluation of the level of financial globalisation of prime importance. First, financial globalisation became a universal process rather recently, in the 1990-s. Thus, such a process is-well documented, while an opposite observation could be made that both theory and terminology are not yet established. Intense research is taking place, but there are a number of schools and approaches. Second, the topic of financial globalisation became vital after the breakup of the recent financial crisis. Major economists point out that various financial liberalisation processes, which constitute the process of financial globalisation, obstruct financial stability and deepen aftermath negative effects of crises (Kose et al. 2009). Also, majority of studies claim that financial globalisation positively effects economic growth (Podviezko 2013). Many attempts were made to quantitatively measure the level of the financial liberalisation processes. Such attempts can be treated as the first necessary step for the researchers, who attempt to find out, if financial globalisation produces negative effects on financial stability; on economic growth; if institutions may provide a synergy with the liberalising reforms thus increasing probability of economic growth; etc.
Financial globalisation is an integral process of globalisation. On the other hand, financial globalisation comprises a number of processes itself. Such a complexity can make comprehension of the topic rather vague. In addition, to be more specific now, terminology of both globalisation and financial globalisation processes is not yet established.

This results in the whole variety of different approaches to measurement of financial globalisation, and in plethora of different, often diverse, sets of criteria, which quantitatively describe and gauge the level of financial globalisation.

And the contemporary developing state of the subject is well understood. Globalisation processes commenced to expand after the end of certain landmarks of history, which happened quite recently such as the end of colonisation, the end of vitality of centralised social systems and the end of their extreme cases - dictatorships. Strategy of increasing of welfare of the people started to sub-dominate other local strategies within majority of states, which inevitably leaded to rationalisation of use of resources, specialisation, increased co-operation between nations, and globalisation as a consequence (Hoffmann 2002). 
Lithuania as other post-Soviet countries launched to the financial globalisation process in time right after the break-up of the Soviet Union as the 1990-s are notable for global increase of financial globalisation. Global picture of dynamics of reforms towards financial liberalisation is provided in a very interesting research paper (Tressel, Detragiache 2008), in which the authors evaluated undertaken reforms in 91 countries in the period of 1974-2005. They used so-called de jure sub-criteria, 7 in total, which were comprised into a single cumulative criterion as a sum of all values of subcriteria. Each sub-criterion can take values from 0 to 3; thus the cumulative criterion was ranging from 0 to 21 . Dynamics of the value of the criterion over the period provides a clear historical vision of dynamics of financial liberalisation: sharp increase of financial liberalisation reforms in the $90-\mathrm{s}$.

In contrast, before the 1970-s most of countries pursued closed and restrictive financial policies, which were worlds away from contemporary prevailing financial globalisation policies (Shaw 1973; McKinnon 1973).

Consequently, the topic of financial globalisation became increasingly important recently. Nevertheless, yet terminology of the topic is intertwined and not fully established. The paper attempts to review different approaches to financial globalisation and to provide criteria for quantitative evaluation of the level of financial globalisation used by different authors.

Purpose of study is to reveal complexity of evaluation of of financial globalisation importance of such evaluation.

Principal objectives of the study are the following. To provide a succinct description of historical landmarks, categorisation of processes of financial globalisation, outline existing approaches of the topic, to reveal importance of the topic, to highlight differences in existing terminology.

Methods employed: comparative analysis, comparative analysis, induction, deduction, synthesis.

\section{Categorisation of processes of financial globalisation}

Categorisation of processes of financial globalisation allows to comprehend contemporary hypotheses and research on effects of financial globalisation on financial development and economic growth in particular.

The latter example of a serious attempt to gauge financial globalisation (Abiad et al. 2008) could be used to demonstrate the variety of approaches and, more specifically, criteria of evaluation of financial globalisation used in the contemporary research. We have taken three similar studies, which evaluate the level of financial globalisation. In Table 1 comparison of sets of chosen sub-criteria

Table 1. Comparison of sets of chosen sub-criteria in research papers gauging historical levels of financial liberalisation (Source: compiled by the author with reference to Laeven (2003); Abiad et al. (2008); Mody, Murshid (2002))

\begin{tabular}{|c|c|c|}
\hline Laeven (2003) & Abiad et al. (2008) & Mody, Murshid (2002) \\
\hline Interest rate controls & Interest rate controls & - \\
\hline $\begin{array}{l}\text { Entry barriers to establish a foreign } \\
\text { or local commercial bank }\end{array}$ & $\begin{array}{l}\text { Entry barriers to establish a foreign } \\
\text { or local commercial bank }\end{array}$ & - \\
\hline $\begin{array}{l}\text { Credit controls and high reserves } \\
\text { requirements }\end{array}$ & $\begin{array}{l}\text { Credit controls and high reserves } \\
\text { requirements }\end{array}$ & \\
\hline $\begin{array}{l}\text { State bank proportion in the com- } \\
\text { mercial banking sector }\end{array}$ & $\begin{array}{l}\text { State bank proportion in the com- } \\
\text { mercial banking sector }\end{array}$ & - \\
\hline Commercial bank supervision & Bank regulations & - \\
\hline- & Constraints on capital account & Capital account constraints \\
\hline- & Constraints on securities market & - \\
\hline- & - & Constraints on internaional transfers \\
\hline- & - & Constraints on export proceeds \\
\hline- & - & Multiple foreign exchange rates \\
\hline \multicolumn{3}{|l|}{ Notes on values of sub-criteria } \\
\hline $\begin{array}{l}\text { Value of each sub-criterion is as- } \\
\text { signed } 1 \text {, if the condition is fulfilled; } \\
0 \text { if the Condition is not fulfilled }\end{array}$ & $\begin{array}{l}\text { Value of each sub-criterion is as- } \\
\text { signed from } 0 \text { to } 3 \text { ( } 3 \text { denotes fully } \\
\text { liberalised State; } 2 \text { - partially liberal- } \\
\text { ised state; } 1 \text { - some constraints are } \\
\text { existing; } 0 \text { - fully controlled) }\end{array}$ & $\begin{array}{l}\text { Value of each sub-criterion is as- } \\
\text { signed } 1 \text {, if the condition is fulfilled; } \\
0 \text { if the Condition is not fulfilled }\end{array}$ \\
\hline
\end{tabular}


of two other research papers gauging historical levels of financial liberalisation Laeven (2003) and Mody, Murshid (2002) with the ones used in Abiad et al. (2008) (located in the middle column of the Table 1), is presented.

Both terminology used in the topic and approaches in evaluation of levels of financial globalisation considerably differ, the broad categorisation of processes of financial globalisation was designed to provide a global view to the processes taking place within financial globalisation (Podviezko 2014, Table 2).

The author discerns two levels of financial liberalisation (Table 2): the international, and the domestic. Paradoxically, domestic criteria of financial liberalisation are not included into major indices of quantitative evaluation of the level of globalisation, which are listed in Section 5. Nevertheless, the following non-financial, different, sub-criteria at the domestic level can be found in such indices: Human Capital; Social \& Cultural; People; etc. Financial criteria of financial liberalisation, such as legislation and supervision of both bank-based and marketbased financial sub-systems are not incorporated into the indices of globalisation.

Table 2. Structure of processes of financial liberalisation (Source: Podviezko (2014))

\begin{tabular}{l|l|l}
\hline & \multicolumn{1}{|c|}{$\begin{array}{c}\text { Bank-based } \\
\text { financial system }\end{array}$} & $\begin{array}{c}\text { Market-based } \\
\text { financial system }\end{array}$ \\
\hline \multirow{2}{*}{$\begin{array}{l}\text { International } \\
\text { level }\end{array}$} & Capital account liberalisation \\
\cline { 2 - 3 } & Current account liberalisation \\
\hline $\begin{array}{l}\text { Domestic } \\
\text { level }\end{array}$ & Legislation \\
\cline { 2 - 3 } & $\begin{array}{l}\text { Supervision of the } \\
\text { banking sector }\end{array}$ & $\begin{array}{l}\text { Supervision of } \\
\text { the stock market }\end{array}$ \\
\hline
\end{tabular}

The international level of financial liberalisation usually comprises such criteria as current account liberalisation, capital account liberalisation, stock market liberalisation for foreign investors, and creates opportunities for the country's financial integration to the international financial system. At the domestic level financial liberalisation includes creation of the appropriate legislation, reforms in the banking sector and the stock market.

It is notable that an approach from a different political - perspective also yielded a similar twolayer categorisation of processes of financial liberalisation (Burgoon et al. 2012, Table 3).

The concept of financial globalisation mainly means reducing State control over the financial sector or deregulation of the financial sector. Nevertheless, abolishment of State control is only the starting point. Remaining problems comprise the concept of the financial liberalisation, which has not been elaborated to become widely acceptable yet. For example, Palgrave financial dictionary mentions only two integral parts of financial liberalisation: deregulation of domestic stock market, and capital account liberalisation (Rancière et al. 2008). Consequently, more specific realms of investigation of financial liberalisation can be found in the literature: current account liberalisation; stock market liberalisation for foreign investors, etc.

Table 3. Sources of legitimacy of financial openness at different levels of governance (Source: Burgoon et al. 2012)

\begin{tabular}{l|l|l}
\hline & \multicolumn{1}{|c}{$\begin{array}{c}\text { Input } \\
\text { legitimacy }\end{array}$} & \multicolumn{1}{c}{$\begin{array}{c}\text { Output } \\
\text { legitimacy }\end{array}$} \\
\hline $\begin{array}{l}\text { International } \\
\text { level }\end{array}$ & $\begin{array}{l}\text { International Voter } \\
\text { support for } \\
\text { Non-free-market } \\
\text { internationalisation }\end{array}$ & $\begin{array}{l}\text { Foreign aid } \\
\text { (multi-national, } \\
\text { bilateral) }\end{array}$ \\
\hline $\begin{array}{l}\text { Domestic } \\
\text { level }\end{array}$ & $\begin{array}{l}\Delta \text { Left government } \\
\text { Left government x } \\
\text { Democracy }\end{array}$ & $\begin{array}{l}\text { Social policy } \\
\text { compensation } \\
\text { (e.g. health } \\
\text { spending) }\end{array}$ \\
\hline
\end{tabular}

\section{Different approaches to gauge financial globalisation}

Quinn (2003) uses a supplementary term related to financial globalisation: financial openness. The latter research is focusing primarily in capital account liberalisation as a measure of financial openness. In the paper by Arestis (2002) a clear logic was stated that a necessary but not sufficient condition for financial globalisation is financial liberalisation, while the sufficient condition is the introduction of a worldwide single currency managed by a single international monetary authority. This approach was reinforced in Pop, Valeriu (2015). We note that the latter authors expanded the concept and named sustainable development conditions as necessary for financial globalisation (economy, environment, social responsibilities) besides existence of a single currency, and quality of life tied with diminishing of inequality.

An initial approach to the categorisation of processes of financial globalisation are stated in Helleiner (1995), where its three integral processes are named: first, granting freedom to markets; second, financial crisis prevention, and third, lose or nil controls on financial movements. The list of processes of financial globalisation gradually expanded over the years. Focus on both trade liberalisation and capital account liberalisation (or opening of financial markets) as two integral processed of globalisation can 
be observed in the paper by Mishkin (2009), which also suggests positive effects of globalisation on economic growth. In Campenhout and Cassimon (2012), where country risk variables were related to quality of institutional environment and effects of financial globalisation on economic growth were estimated, the following processes were named to reflect financial globalisation: capital account liberalisation; equity market liberalisation.

Baltagi et al. (2009) use two following dimensions in order to measure openness of a country: trade openness and financial openness and relate both measures to explain the pace of financial development of countries. The research is not limited to the countries with the bank-based financial system (Podviezko 2015) as they measure development of financial system using criteria, which relate both to the bank-based sub-system (private credit to GDP) and to the market-based sub-system (stock market capitalisation to GDP) of the financial system. A positive relationship between financial and economic development is often found in the literature (Deltuvaite, Sinevičiene 2014) thus making the former component important.

Some research papers concentrate specifically on measurement of capital account liberalisation as an integral part of financial globalisation (Eichengreen et al. 2011; Prasad, Rajan 2008).

\section{Importance of evaluation of financial globalisation level}

Plethora of studies on effects of financial globalisation on economic growth exposes the level of interest to this topic.

Financial liberalisation, a concept, which was developed by McKinnon (1973) and Shaw (1973), was initially believed to empower financial systems to make positive effects on economic growth. The hypothesis of financial liberalisation implies that reduction of control over financial systems would make interest rates for savings instruments more attractive. This consequently should have increased the level of funds to be available for crediting enterprises. The following increase of depth of financial system should then have fostered the economic growth (Moore 2010). Nevertheless, this hypothesis is currently not widely accepted because its empirical testing in the real life appeared to be more different than it was expected mostly due to effects of financial crises.

The complexity of the topic is wider than terminology or variety of criteria and their quantity. There is a broad perspective of research of influence of financial liberalisation on various economic processes. A succinct overview of available directions of research of effects of financial liberalisation is presented hereafter.

- Influence of liberalisation of trade on financial liberalisation (Hauner et al. 2013; (Chinn et al. 2006).

- Influence of liberalisation of trade on growth of economy (Kose et al. 2009; Razin, Rose 1992; Sachs et al. 1995).

- Effects of capital account liberalization and corruption (Kunieda et al. 2014).

- Influence of capital account liberalization and income inequality (Bumann et al. 2013; Bergh, Nilsson 2010; Yiping et al. 2014; Dong 2014; Sheng 2015).

- Gauging the level of financial liberalisation (Abiad et al. 2008; Abiad, Mody 2003; Laeven 2003; Mody, Murshid 2002; Kaminsky, Schmukler 2003; Demirgüç-Kunt, Detragiache 1998; Lane et al. 2007; Chinn, Ito 2007; Quinn, Toyoda 2008, Transition Reports by the IMF; World Economic Outlook by the World Bank, etc.).

- Influence of politics on financial liberalisation (Burgoon et al. 2012).

- Influence of financial liberalisation on financial stability (Podviezko 2014, 2015; Carmignani et al. 2007; Aizenman et al. 2008; Lee et al. 2016; Eichacker 2015; Hamdi, Jlassi 2014; Cubillas, González 2014; Agnello et al. 2015; Creel et al. 2015).

- Influence of financial liberalisation on prudential policy (Beju, Ciupac-Ulici 2012).

- Influence of financial liberalisation on innovation (Ang 2014).

Analysis of 441 research papers revealed full perplexity of obtained results (Bumann et al. 2013):

- only a weak effect of financial liberalisation on growth is observed;

- a broad range of additional actions are proposed to make effect of growth more predictable (fiscal, monetary policies, institutional changes focussing on regulation of financial markets);

- nevertheless, it was observed that for countries with less developed financial systems, financial liberalization has more value in terms of stimulating economic growth.

It could be observed that currently influence of financial globalisation on such prime economic processes as economic growth, corruption; income inequality; politics; financial stability; prudential policy is vaguely explained. More reliable methods 
should be used along with statistical methods currently employed. Multiple criteria decision-aid methods are not only most popular and reliable for evaluation of socio-economic processes, but along with results they also provide tools for explaining causes of the effect observed (Brauers et al. 2014; Brauers et al. 2012; Ginevicius, Podviezko 2013; Krivka 2014; Podviezko 2012; Podviezko, V., Podvezko, A. 2014, 2010).

\section{Financial globalisation dimension in popular available globalisation indexes}

Globalisation itself is closely related to financial globalisation as various financial instruments facilitate exports and imports between countries $(\mathrm{Wu}$ 2012). In some studies terms of financial globalisation and financial liberalisation are used interchangeably, without making strict difference between the terms (e.g. Arin 1999). Prasad et al. (2003) explain the difference between terms of financial integration and financial globalisation. In case if integration of a country's financial system to the world financial system is investigated, the term integration is used. On the other hand, if financial flows and relationships are investigated, the globalisation term is used.

Research papers devoted to quantitative evaluation of globalisation use different terms to describe financial globalisation component. In the description of the KOF and The Maastricht indices of globalisation the term "Economic Globalisation" is used for naming the related category of criteria. Besides the named category, the KOF index of globalisation consists of the following categories: social globalisation; and political globalisation (Dreher 2006). And The Maastricht Index of Globalisation besides Economic Globalisation category uses Political; Social \& Cultural; Technological; and Environmental categories (Figge, Martens 2014). Depth index of globalization (DIG) instead of financial globalisation category uses the category "Capital". And three other categories "Trade"; "Information"; and "People" (Ghemawat, Altman 2013). The A.T. Kearney Global Cities Index (GCI), which ranks 125 cities according to 27 metrics across five dimensions, uses "Business activity" category of criteria, which are representing Economic Globalisation. Besides this category the index uses the following categories of criteria: human capital, information exchange, cultural experience, and political engagement (Hales et al. 2014).

Categorisation of sub-criteria of popular globalisation indices is provided in Table 4 .

The sub-criteria found in the economic globalisation category could be classified as is presented on Figure 1 (Žitkauskaite 2014; World Trade Organization 2014).

As is observed in Figure 1 more trade liberalisation criteria are used for "gauging economic globalisation" compared to criteria involved in gauging financial globalisation.

Table 4. Categories of sub-criteria, used in popular indices of quantitative evaluation of the level of globalisation (Source: compiled by the author with reference to Dreher (2006); Figge, Martens (2014); Ghemawat, Altman (2013); Hales et al. (2014))

\begin{tabular}{l} 
Category \\
\cline { 2 - 8 } Index
\end{tabular}




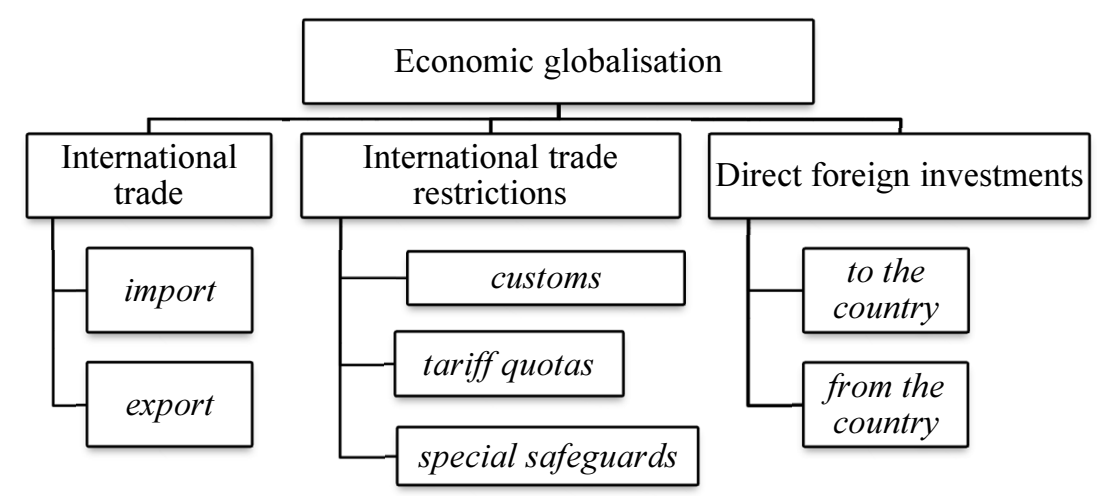

Fig. 1. Categorisation of Economic Globalisation criteria. (Source: compiled by the author with reference to Žitkauskaitė 2014)

\section{Conclusions}

We can derive principal conclusions from the paper as follows. In the topic of financial globalisation currently many dimensions are revealed; consequently, there is a broad categorisation of criteria gauging financial globalisation; as approaches considerably differ, both different incongruent terminology is used by researchers, and categorisation of criteria considerably differ. Accurate evaluation of the level of financial globalisation is crucial for allowing further important research to be carried out, which could explain often currently vaguely explained influence of financial globalisation on such prime economic processes as economic growth, corruption; income inequality; politics; financial stability; prudential policy. Investigations on globalisation in terms of economic dimension stand yet far off investigations on financial liberalisation.

Results of the study are as follows. A succinct description of historical landmarks was provided. Categorisation of processes of financial globalisation is proposed. Existing approaches of the topic were outlined. Importance of the topic was highlighted. Major differences in existing terminology were pointed out.

\section{References}

Abiad, A.; Detragiache, E.; Tressel, T. 2008. A new database of financial reforms, IMF Working Paper WP/08/266: 1-28.

Abiad, A.; Mody, A. 2003. Financial reform: What shakes it? What shapes it?, IMF working paper WP/03/70: 1-39.

Agnello, L.; Sousa, R. M. 2015. Can re-regulation of the financial sector strike back public debt?, Economic Modelling 51: 159-171.

http://dx.doi.org/10.1016/j.econmod.2015.07.018
Aizenman, J.; Chinn, M. D.; Ito, H. 2008. Assessing the emerging global financial architecture: measuring the trilemma's configurations over time, NBER working paper series 14533: 1-58.

Ang J. B. 2014. Innovation and financial liberalization, Journal of Banking \& Finance 47: 214-229. http://dx.doi.org/10.1016/j.jbankfin.2014.07.007

Arestis, P. 2002. Working paper No. 360 financial globalization: some conceptual problems, European Economic Review (360): 1-5.

Arin, T. 1999. Financial markets and globalization in turkey, Topics in Middle Eastern and North African Economies 1: 1-8.

Baltagi, B. H.; Demetriades, P. O.; Law, S. H. 2009. Financial development and openness: evidence from panel data, Journal of Development Economics 89(2): 285-296.

http://dx.doi.org/10.1016/j.jdeveco.2008.06.006

Beju, D. G.; Ciupac-Ulici, M.-L. 2012. the impact of financial liberalization on banking system, Procedia Economics and Finance 3: 792-799. http://dx.doi.org/10.1016/S2212-5671(12)00232-8

Bergh, A.; Nilsson, T. 2010. Do liberalization and globalization increase income inequality?, European Journal of Political Economy 26(4): 488-505. http://dx.doi.org/10.1016/j.ejpoleco.2010.03.002

Brauers, W.; Ginevicius, R.; Podviezko, A. 2014. Development of a methodology of evaluation of financial stability of commercial banks, Panoeconomicus 61(3): 349-367.

http://dx.doi.org/10.2298/PAN1403349B

Brauers, W. K.; Ginevicius, R.; Podviezko, A. 2012. Evaluation of performance of Lithuanian commercial banks by multi-objective optimization in R. Ginevicius, A. V Rutkauskas; J. Stankeviciene (Eds.). The $7^{\text {th }}$ International Scientific Conference Business and Management'2012, May 10-11, Vilnius, Lithuania: Selected papers. Vilnius, Lithuania: Technika. 
Bumann, S.; Hermes, N.; Lensink, R. 2013. Financial liberalization and economic growth: a meta-analysis, Journal of International Money and Finance 33: $255-281$. http://dx.doi.org/10.1016/j.jimonfin.2012.11.013

Burgoon, B.; Demetriades, P.; Underhill, G. R. D. 2012. Sources and legitimacy of financial liberalization, European Journal of Political Economy 28(2): 147-161. http://dx.doi.org/10.1016/j.ejpoleco.2011.10.003

Campenhout, V. B.; Cassimon, D. 2012. Multiple equilibria in the dynamics of financial globalization: the role of institutions, Journal of International Financial Markets, Institutions and Money 22(2): 329 342. http://dx.doi.org/10.1016/j.intfin.2011.10.002

Carmignani, F.; Colombo, E.; Tirelli, P. 2007. Socio-political and economic determinants of de facto monetary institutions and inflationary outcomes, University of Milan - Bicocca Working Paper Series 107: $1-28$.

Chinn, M. D.; Ito, H. 2007. A new measure of finanial openness, Journal of Comparative Policy Analysis: Research and Practice 10(3): 1-18. http://dx.doi.org/10.1080/13876980802231123

Chinn, M. D.; Ito, H. 2006. What matters for financial development? Capital controls, institutions, and interactions, Journal of Development Economics 81(1): 163-192. http://dx.doi.org/10.1016/j.jdeveco.2005.05.010

Creel, J.; Hubert, P.; Labondance, F. 2015. Financial stability and economic performance, Economic Modelling 48: 25-40.

http://dx.doi.org/10.1016/j.econmod.2014.10.025

Cubillas, E.; González, F. 2014. Financial liberalization and bank risk-taking: International evidence, Journal of Financial Stability 11: 32-48. http://dx.doi.org/10.1016/j.jfs.2013.11.001

Deltuvaite, V.; Sinevičienè, L. 2014. Investigation of relationship between financial and economic development in the EU countries, Procedia Economics and Finance 14(2009): 173-180. http://dx.doi.org/10.1016/S2212-5671(14)00700-X

Demirgüç-Kunt, A.; Detragiache, E. 1998. Financial liberalization and financial fragility, IMF Working Paper No. 98/83: 1-36.

http://dx.doi.org/10.5089/9781451850512.001

Dong, F. 2014. The impact of economic openness on standard of living and income inequality in eight countries, Emerging Markets Review 21: 234-264. http://dx.doi.org/10.1016/j.ememar.2014.09.005

Dreher, A. 2006. Does globalization affect growth? Evidence from a new index of globalization, Applied Economics 38(10): 1091-1110. http://dx.doi.org/10.1080/00036840500392078

Eichacker, N. 2015. Financial liberalization and the onset of financial crisis in Western European states between 1983 and 2011: an econometric investigation,
The North American Journal of Economics and Finance 34: 323-343.

Eichengreen, B.; Gullapalli, R.; Panizza, U. 2011. Capital account liberalization, financial development and industry growth: A synthetic view, Journal of International Money and Finance 30(6): 1090-1106. http://dx.doi.org/10.1016/j.jimonfin.2011.06.007

Figge, L.; Martens, P. 2014. Globalisation continues: the maastricht globalisation index revisited and updated, Globalizations 11(6): 875-893. http://dx.doi.org/10.1080/14747731.2014.887389

Ghemawat, P.; Altman, S. A. 2013. Depth index of globalization 2013: and the big shift to emerging economics. New York: Pankaj Ghemawat.

Ginevicius, R.; Podviezko, A. 2013. The evaluation of financial stability and soundness of Lithuanian banks, Ekonomska Istrazivanja-Economic Research 26(2): 191-207. http://dx.doi.org/10.1080/1331677X.2013.11517616

Hales, M.; Peterson, E.; Mendoza Peña, A.; Gott, J. 2014. Global cities, present and future, Chicago: A. T. Kearney, Inc.

Hamdi, H.; Jlassi, N. B. 2014. Financial liberalization, disaggregated capital flows and banking crisis: evidence from developing countries, Economic Modelling 41: 124-132. http://dx.doi.org/10.1016/j.econmod.2014.05.010

Hauner, D.; Prati, A.; Bircan, C. 2013. The interest group theory of financial development: Evidence from regulation, Journal of Banking \& Finance 37(3): 895-906.

http://dx.doi.org/10.1016/j.jbankfin.2012.10.008

Helleiner, E. 1995. Explaining the globalization of financial markets: bringing states back in, Review of International Political Economy 2(2): 315-341. http://dx.doi.org/10.1080/09692299508434322

Hoffmann, S. 2002. Clash of globalizations. Tampa, FL: Foreign Affairs.

Kaminsky, G. L.; Schmukler, S. L. 2003. Short-run pain, long-run gain: the effects of financial liberalization, IMF Working Paper WP/03/34: 1-59.

Kose, M. A.; Prasad, E.; Rogoff, K.; Wei, S.-J. 2009. Financial globalization and economic policies, IZA Discussion Paper 4037: 1-86.

Krivka, A. 2014. Complex evaluation of the economic crisis impact on Lithuanian industries, Journal of Business Economics and Management 15(2): 299-315. http://dx.doi.org/10.3846/16111699.2013.867277

Kunieda, T.; Okada, K.; Shibata, A. 2014. Corruption, capital account liberalization, and economic growth: theory and evidence, International Economics 139: 80-108. http://dx.doi.org/10.1016/j.inteco.2014.03.001

Laeven, L. 2003. Does Financial Liberalization Reduce Financing Constraints?, Financial Management 32(1): 5-34. http://dx.doi.org/10.2307/3666202 
Lane, P. R.; Milesi-Ferretti, G. M. 2007. The external wealth of nations mark II: Revised and extended estimates of foreign assets and liabilities, 1970-2004, Journal of International Economics 73(2): 223250. http://dx.doi.org/10.1016/j.jinteco.2007.02.003

Lee, C.-C.; Lin, C.-W.; Zeng, J.-H. 2016. Financial liberalization, insurance market, and the likelihood of financial crises, Journal of International Money and Finance 62: 25-51. http://dx.doi.org/10.1016/j.jimonfin.2015.12.002

McKinnon, R. I. 1973. Money and capital in economic development. Washington, DC: Brookings Institution.

Mishkin, F. S. 2009. Globalization and financial development, Journal of Development Economics 89(2): 164-169. http://dx.doi.org/10.1016/j.jdeveco.2007.11.004

Mody, A.; Murshid, A. P. 2002. Growing up with capital flows, IMF Working Paper WP/02/75: 1-31.

Moore, T. 2010. A Critical appraisal of McKinnon's complementarity hypothesis: does the real rate of return on money matter for investment in developing countries?, World Development 38(3): 260-269. http://dx.doi.org/10.1016/j.worlddev.2009.09.010

Podvezko, V.; Podviezko, A. 2010. Dependence of multicriteria evaluation result on choice of preference functions and their parameters, Technological and Economic Development of Economy 16(1): 143158. http://dx.doi.org/10.3846/tede.2010.09

Podviezko, A. 2012. Augmenting multicriteria decision aid methods by graphical and analytical reporting tools in L. Niedrite; R. Strazdina; B. Wangler (Eds.). Lecture notes in business information processing. Berlin, Heidelberg: Springer Verlag.

Podviezko, A. 2013. Evaluation of financial stability of commercial banks: Doctoral dissertation. Vilnius, Lithuania: Technika (in Lithuanian).

Podviezko, A. 2014. Influence of processes of transformation of economy on financial stability, in The $8^{\text {th }}$ International Scientific Conference ,Business and Management 2014“, 16 May 2014, Vilnius, Lithuania. Vilnius, Lithuania: Vilnius Gediminas Technical University Publishing House Technika. http://dx.doi.org/10.3846/bm.2014.068

Podviezko, A. 2015. Type of the Lithuanian financial system, Procedia Economics and Finance 23: 1635-1640. http://dx.doi.org/10.1016/S2212-5671(15)00378-0

Podviezko, A.; Ginevičius, R. 2010. Economic criteria characterising bank soundness and stability in The $6^{\text {th }}$ International Scientific Conference „Business and Management 2010“, 13-14 May, 2010, Vilnius, Lithuania: Selected papers. Vilnius, Lithuania: Vilnius Gediminas Technical University Publishing House Technika. http://dx.doi.org/10.3846/bm.2010.144

Podviezko, A.; Podvezko, V. 2014. Absolute and relative evaluation of socio-economic objects based on multiple criteria decision making methods, Engineering Economics 25(5): 522-529. http://dx.doi.org/10.5755/j01.ee.25.5.6624

Pop, N.; Valeriu, I.-F. 2015. Crisis, globalisation, global currency, Procedia Economics and Finance 22: 479-484. http://dx.doi.org/10.1016/S2212-5671(15)00242-7

Prasad, E. S.; Rajan, R. G. 2008. A pragmatic approach to capital account liberalization, Journal of Economic Perspectives 22(3): 149-172. http://dx.doi.org/10.1257/jep.22.3.149

Prasad, E. S.; Rogoff, K.; Wei, S.-J.; Kose, M. A. 2003. Effects of financial globalization on developing countries: some empirical evidence, IMF Occasional Paper 220: 1-86.

Quinn, D. P. 2003. Capital account liberalization and financial globalization, 1890-1999: a synoptic view, International Journal of Finance \& Economics 8(3): 189-204. http://dx.doi.org/10.1002/ijfe.209

Quinn, D. P.; Toyoda, A. M. 2008. Does capital account liberalization lead to growth?, Review of Financial Studies 21(3): 1403-1449.

http://dx.doi.org/10.1002/ijfe.209

Rancière, R.; Tornell, A.; Westermann, F. 2008. Financial liberalization, in S. N. Durlauf; L. E. Blume (Eds.). The new palgrave dictionary of economics. Basingstoke: Palgrave Macmillan. http://dx.doi.org/10.1057/9780230226203.0569

Razin, A.; Rose, A. K. 1992. Business cycle volatility and openness: an exploratory cross-section analysis, NBER Working Paper 4208: 1-31.

Sachs, J.; Warner, A.; Åslund, A.; Fischer, S. 1995. Economic reform and the process of global integration, Brookings papers on economic activity 1995(1): 1118. http://dx.doi.org/10.2307/2534573

Shaw, E. S. 1973. Financial deepening in economic development. Oxford University Press.

Sheng, L. 2015. Theorizing income inequality in the face of financial globalization, The Social Science Journal 52(3): 415-424. http://dx.doi.org/10.1016/j.soscij.2014.06.003

Tressel, T.; Detragiache, E. 2008. Do financial sector reforms lead to financial development? Evidence from a new dataset, IMF Working Paper WP/08/265: 1-42.

World Trade Organization. 2014. World tariff profiles. Geneva: WTO Publications.

Wu, F. 2012. Globalisation, in S. J. Smith (Eds.). International encyclopedia of housing and home. Amsterdam: Elsevier. http://dx.doi.org/10.1016/B9780-08-047163-1.00631-7

Yiping, H.; Qin, G.; Xun W. 2014. Financial liberalization and the middle-income trap, China Economic Review 31: 426-440. http://dx.doi.org/10.1016/j.chieco.2014.04.009

Žitkauskaitè, S. 2014. Ekonomikos globalizavimo tendencijos. Vilnius, Lithuania: Mykolas Romeris University. 